“'War... What Is It Good For?' Laughter and Ratings": Sgt. Bilko, $M^{*} A^{*} S^{*} H$ and the Heyday of U.S. Military Sitcoms (1955-75)

\title{
Dennis Tredy
}

\section{(2) OpenEdition}

Journals

Electronic version

URL: http://journals.openedition.org/tvseries/1764

DOI: $10.4000 /$ tvseries. 1764

ISSN: 2266-0909

Publisher

GRIC - Groupe de recherche Identités et Cultures

\section{Electronic reference}

Dennis Tredy, " "War... What Is It Good For?' Laughter and Ratings": Sgt. Bilko, M*A*S*H and the Heyday of U.S. Military Sitcoms (1955-75)», TV/Series [Online], 10 | 2016, Online since 01 December 2016, connection on 05 May 2019. URL : http://journals.openedition.org/tvseries/1764 ; DOI : 10.4000/ tvseries.1764

This text was automatically generated on 5 May 2019.

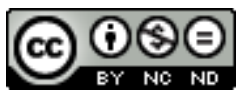

TV/Series est mis à disposition selon les termes de la licence Creative Commons Attribution - Pas d'Utilisation Commerciale - Pas de Modification 4.0 International 


\title{
“'War... What Is It Good For?' Laughter and Ratings": Sgt. Bilko, $M^{*} A^{*} S^{*} H$ and the Heyday of U.S. Military Sitcoms (1955-75)
}

\author{
Dennis Tredy
}

1 If the title of this paper quotes part of the refrain from Edwin Starr's 1970 protest song, "War," the song's next line, proclaiming that war is good for "absolutely nothing" seems inaccurate, at least in terms of successful television sitcoms of from the 1950s to the 1970s. In fact, while Starr's song was still an anti-Vietnam War battle cry, groundbreaking television programs like $M^{*} A^{*} S^{*} H$ (CBS, 1972-1983) were using laughter and tongue-in-cheek treatment of the horrors of war to provide a somewhat more palatable expression of the growing anti-war sentiment to American audiences. The program was an integral part of CBS's 1970s line-up of "relevancy programming" and "serious comedies" that made the network the indisputable ratings leader on US television, a lineup which included All in the Family (1971-79), The Mary Tyler Moore Show (1970-77) and their vast networks of spin-offs and lookalikes, and which collectively dealt with the most divisive social issues of the time (racism, sexism, war protest, divorce, etc.) by means of irreverent and even slapstick humor.

2 Yet we tend to put $M^{*} A^{*} S^{*} H$ on such a pedestal today that we forget that, on US television, it was in fact part of one of the last waves of TV's war comedies, an oxymoron if there ever was one, and a hybrid sub-genre that began in the mid-1950s. Long before $M^{*} A^{*} S^{*} H$ set up camp as one of the most popular and powerful television shows of the 1970s, many veteran military sitcoms had long-since finished their tour of duty, some with more honors than others, but all with the same marching orders as $M^{*} A^{*} S^{*} H$, the belief that "laughter is the best medicine". There were in fact three distinct waves of military sitcom over the thirty-year period, all three of which were somehow dominated by CBS. The first wave, of the late 1950s, included only two sitcoms, both on CBS, though one in particular, 
You'll Never Get Rich / The Phil Silvers Show (1955-59) would be one of the three most popular programs of the era and, as this study will show, would set up the basic comedic conventions that nearly all military comedies would thereafter rely upon. The second wave, that of the 1960s, would rely very heavily on that early model and would see a far greater number of military series on U.S. television-with eleven different such sitcoms on all three networks-though none would have the anti-establishment bite that Phil Silvers's program had provided. The 1970s would then see the third and final wave, and a return to harder-hitting military comedy, as the period was dominated by CBS's $M^{*} A^{*} S^{*} H$ and lasted for the duration of that landmark series, from 1972 to 1983-both crushing the other networks' feeble attempts to modernize the military sitcom and proving that wartime situation comedy could indeed deal with hard-hitting and disturbing social issues.

3 This study will then focus on the two landmark military sitcoms that bookended that three-decade era that could be considered the 'heyday of military sitcoms'. The first, The Phil Silvers Show-along with its sources and influences and the conventions it established -is of utmost importance to understanding all of the American military comedies that would follow it. It would even provide the basic matrix for the last wave of the 1970s and its landmark work of anti-establishment sentiment and social criticism through military comedy, $M^{*} A^{*} S^{*} H$.

\section{Sgt. Bilko Sets up Camp and Leads the Charge}

\subsection{Film Sources for the Bilko Model}

If the military sitcom was born in 1955 behind the spectacles and uniform of Phil Silver's landmark character Sgt. Bilko, many of its conventions had in fact already been established in military comedy films released in the 1940s and early 1950s. Jeanine Basinger, in her landmark study of the World War II Combat Films ${ }^{1}$, focuses on Hollywood military dramas, the first wave of which came between 1941 and 1943, during the peacetime draft in the run-up to World War II and in the early days of America's direct involvement in the war effort (55-57). This initial period, for Basinger, first defined and established the conventions of the combat genre that would be exploited and modified in four successive film waves over 30 years. However, we could say that the same goes for the conventions of military sitcoms, as their conventions were, it seems, first established in feature films in 1941, when Bud Abbott and Lou Costello rose to fame through three successive slapstick military comedies, released in January, May and November of 1941, thereby launching a spate of lookalike peacetime military comedies in addition to their own.

These 'wacky' military comedies included Buck Privates, in which Abbott and Costello (as 'Slicker and Herbie') accidentally join the army and are sent to boot camp; In the Navy, in which, as 'Smokey and Pomeroy', the two stooges wreak harmless havoc on a Navy ship; and Keep 'Em Flying, in which the pair, as Blackie and Heathcliffe, bring their banter and slapstick shenanigans to the air by joining the air force. So as not to let Universal be the only corporation to benefit from this new genre, other studios joined the ranks and marched out their own lookalikes during that same year, one of which is particularly important as it co-starred Phil Silvers, who would go on to create and star in the first television military sitcom as Sgt. Bilko. This Warner Bros. production was called You're in 
the Army Now!, borrowing a line from the refrain of a famous army marching ditty, and it starred funny-man and singer Jimmy Durante and his side-kick, Broadway and radio comic Phil Silvers, as two vacuum-cleaner salesmen who accidentally enlist in the army. It is hard for us today to imagine the influence this barrage of slapstick comedies, nearly all with similar plots and nearly all mixing comedy, romance and musical numbers, would have on the development of military comedies to come and how they would be used as partial templates fourteen years later when military comedy would come to television (see Plate 1).

Plate 1-1941 Film posters: Abbott and Costello's Buck Privates, In the Navy and Keep 'Em Flying, as well as the lookalike You're in the Army Now, starring Jimmy Durante and Phil Silvers

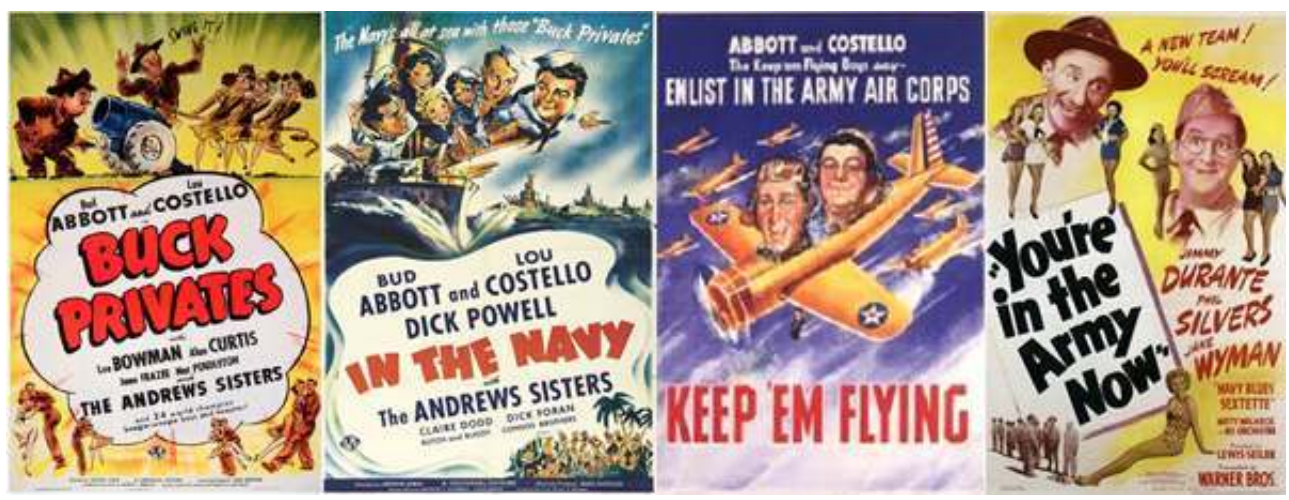

It is important to note that the overall tone of all of these films was very patriotic and sought in no way to criticize or insult the American military itself; on the contrary, the films maintain the pro-war "Why We Fight" message, the same pro-military, propagandistic plugging that Basinger pointed out in dramas of the time (55-57). However, in addition to the patriotic musical numbers by the Andrew Sisters and the recurring romantic plot involving an ideal, All-American soldier, the humor came from the presence of two nitwits who had no place in this man's army. Abbott always played the inveterate conman, able to get out of tough duties and forever caught in hilarious vaudeville banter with his sidekick, the dim-witted and accident-prone Costello character, whose errors and antics would drive his superiors and his wingman up the wall. Together, their idiocy and incompetence knew no bounds-to such a point that the Japanese authorities actually used these movies as misleading training films for their soldiers, so as to demonstrate how ridiculously ill-trained American forces were ${ }^{2}$.

7 Thus the basic palette of comedic devices was established: Banter and wordplay, miscommunication, dereliction of duties, the slapstick antics of two misfits who seem to have no place in an otherwise austere and serious military environment, and a peacetime but war-ready atmosphere in which the main conflict is between the inept duo and their frustrated superior officers.

8 The making of Sgt. Bilko would also be greatly influenced by one of the most popular war comedy-dramas (in literature, on stage and on film) of the immediate post-war era: $\mathrm{Mr}$. Roberts (1946 best-seller by Thomas Heggen, popular 1948 Broadway play by Heggen and Joshua Logan, and 1955 feature film by John Ford). This decade-long legacy of the story of Lt. Roberts would have a great impact both on Sgt. Bilko and on many other service sitcoms of the 1960s. The tone is of course quite different, as this is a darker comedy set during the Pacific campaign of WWII, one that mixes patriotic overtones both with comedic banter and situations as well as with dark drama and tragedy, even ending in the 
death of the main character. Mr. Roberts, though a clever conman, is a far cry from the Bud Abbott prototype, as he is a Lieutenant on the naval ship USS Reluctant at the rearend of the U.S. fleet, who thus never sees combat but longs to fight the good fight (played by Henry Fonda, a paragon on integrity for America audiences, in the film version). He is looked up to by the rest of the crew, a ragtag group of well-intending misfits, and his manipulative skills are aimed at his petty and tyrannical commander, who makes life miserable for the crew through his cruelty and his irrational need for ceremony, paperwork and propriety (Lt. Commander Morton, played by James Cagney in the film). Thus Roberts becomes the protector and chosen leader of the rank-and-file seamen, using his skills to outwit Morton, to protect his fellow men, and to become the war hero he knows he could be. Thus, the Mr. Roberts legacy sets up a clear dynamic: the clever conman and friend to the enlisted man versus the pompous bureaucratic commanderthe same that will be used in Bilko. The antagonist is thus not the nation's military enemy, nor is the butt of the satire the US military's mission itself, but instead the ship's commander, who is too obtuse to see his crew's true worth and the benefits of the rank and file's unconventionality. This point is made abundantly clear when Roberts manipulates his superior to stage an uprising and his own transfer to battle, and when the grateful crew bestows a makeshift medal on him for "action against the enemy" (i.e., Morton). This will provide the key technique used in military comedies on television: the problem is not necessarily the military itself, but it is 'middle-management' as it were, those commanders with abusive or misguided power. In the end, Lt. Powers gets his transfer, becomes a war hero at the Battle of Okinawa, but is later killed in a kamikaze attack. However, the story ends with one of his faithful underlings staging his own rebellion against Lt. Commander Morton, Ensign Pulver, whose character will return in a 1964 sequel to carry on Lt. Roberts's fight with the internal (and eternal) 'enemy', the unfeeling commander.

\subsection{Phil Silvers Sets the Standard}

Phil Silvers would thus rework and combine conventions established by the pre-war and post-war film phenomena mentioned above when creating the first and most iconic American military sitcom, initially entitled You'll Never Get Rich, then The Phil Silvers Show and then, once in syndication, Sgt. Bilko (CBS, 1955-59, 142 episodes). Phil Silvers truly stood out among television comedy stars of the period ${ }^{3}$. Though he started in vaudeville, he was not a stand-up comic as much as he was a comedic actor, earning a name for himself as a remarkably funny character-actor in feature films throughout the 1940 s and as a Broadway sensation in his successful musical comedy Top Banana in 1952. After roasting President Eisenhower at the 1954 Washington Press Club Dinner, Silvers was approached by CBS VP Hubell Robinson with an offer to create his own sitcom. Nat Hiken, with whom he had worked on Broadway, was to be the producer/director/head writer of the show, and they hired a team of veteran writers from the radio circuit (Leonard Stern, Arnold Auerbach, et al.) along with a noted newcomer, Neil Simon ${ }^{4}$. Hiken and Silvers did not initially plan on a military comedy, as initial ideas for the show included Silvers playing a surly Turkish bath attendant, and then the obnoxious brother-in-law to a model American family-until they created Army Master Sergeant Ernest Bilko, who would be anything but 'earnest' and could "bilk" or cheat anyone, as he was a "gambling, scheming, parasitic exploiter of the system at a dreary base in Kansas". 

foray into military comedy, You're in the Army Now, as both titles are lines taken from the same military march that all male viewers of the 1950s, being for the most part either GI's or ex-GI's, knew by heart ("You'll never get rich, by digging a ditch, you're in the army now!"). However, for TV, Phil Silvers would not be playing "second banana" to Jimmy Durante, and they would not be making a mere knock-off of Buck Privates either, for certain devices were borrowed from both the Abbott and costello franchise and from the Mr. Roberts franchise, and the entire program was tailored to fit Silvers' quick-tongued wit.

11 As the title suggests, the army is no place to get rich -unless you're a clever conman like Sgt. Bilko, and even then, your bungling underlings or own better judgment will usually foil the supposedly fool-proof "get-rich-quick" scheme in the end (a device used in The Honeymooners as well, though it was Ralph Kramden himself, and his "big mouth", that always made the plans backfire). Bilko is thus a self-serving conman to some extent, trying to make the most of what seems to be a pointless "peacetime" military force through his gambling winnings and clever schemes. However, it is his position at Fort Baxter-training new recruits under the watchful eye of his commander-that allows for an incredible hybrid of the comedic conventions previously offered on the big screen. As the non-coms ${ }^{6}$ working under him were a ragtag group of misfits and bumbling morons, they recreated hilarious antics, banter and monumental misunderstandings reminiscent of Abbott and Costello, particularly in Bilko's interactions with the fat and dim-witted Pvt. Doberman (Maurice Gosfield). However, if Bilko was a cleverer version of Bud Abbott, he was also a sillier version of Lt. Roberts. Bilko, like Roberts, was a friend to the enlisted man and those under him, and the sworn enemy of his own commander, Colonel Hall (Peter Ford)-an absent-minded stickler for protocol and Bilko's main victim and nemesis -who incidentally was a dead-ringer for then-President Dwight D. Eisenhower, adding a layer of direct political satire to the mix. Bilko was thus the real power at Fort Baxter, the only enemy was his unbending commander and the strict military protocol he attempted to enforce, and Silvers's character always looked out for the little guy and never fleeced more likeable characters.

The formula worked and the show became a top-rated comedy program, winning nine Emmys in the first three years for acting, writing and directing and three consecutive Emmys for Best TV Comedy. Remarkably, the show seamlessly combined slapstick humor with wit and even erudite humor, as the series could showcase, for example, both the antics of dealing with a chimpanzee that was inducted into the army through a series of clerical errors (1.25) and a three-minute rapid-fire speech by Bilko to his psychiatrist on the incompatibility of theories by Freud and by Spinoza when dealing with militaryrelated stress disorders (2.15). It was the boldest and best-written comedy show of its time $^{7}$, and Bilko became a national icon for a clever rascal who knew how to beat the system and could get away with anything. Remarkably, this success continued in spite of the shows' clearly anti-establishment and anti-authority theme... in the 1950s. In a decade known for its remarkable hegemony and conservatism, the show's main themes were that the army is pointless in peacetime, that bureaucracy is inept, that authority is a hypocritical farce and that it is fun to beat the system ${ }^{8}$ (see Plate 2). 
Plate 2-You'll Never Get Rich: Screenshots of Sgt. Bilko (Phil Silvers) laughing it up with his men and standing up to Colonel Hall (Peter Ford).

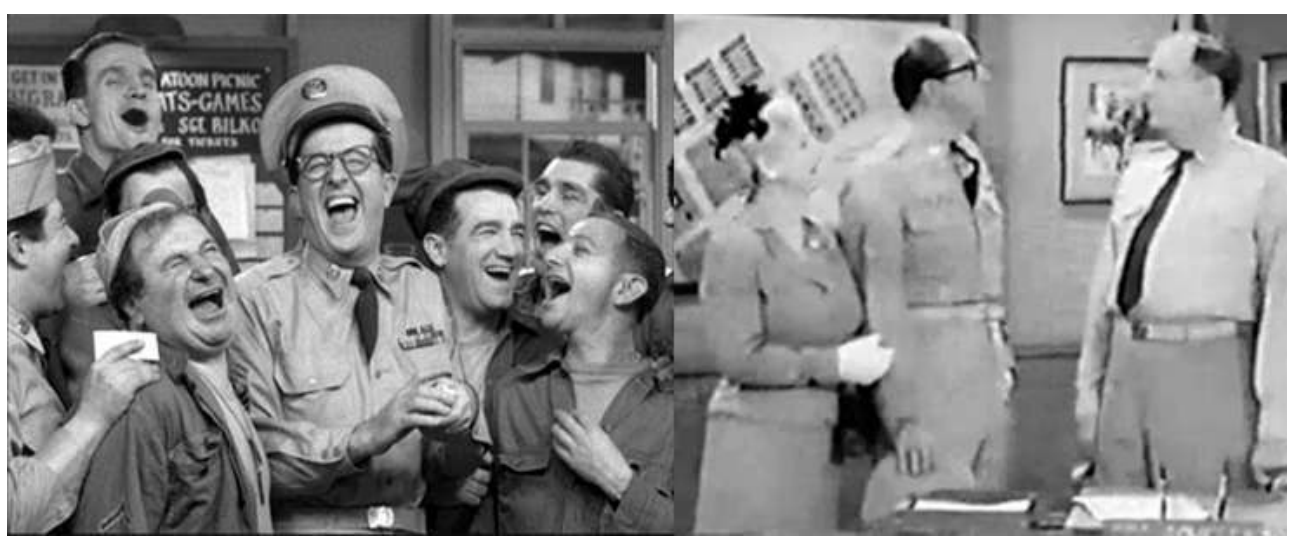

Remarkably, the program outlived most similarly irreverent sitcoms of its period and carried on past 1957, the year that saw the axe fall on a vast majority of popular comedy shows. There was a confluence of factors that caused this change, one of which the rise of a new and popular genre. 1957 was indeed billed on $A B C$ as "The Year of the Adult Western" and had a slew of popular shows that appealed to both men and children (Bilko's main demographic). The other networks followed suit and by the end of the year seven out of the top ten television shows were indeed westerns. Many of the formerly popular comedy hours and sitcoms were cancelled, and many of the most popular TV comics would end up as game show hosts9. In terms of comedy, the late fifties and early sixties saw the dominance of sitcoms with a more conventional, more family-oriented and less ethnic appeal. If 1950s comedy shows were hosted in a vast majority by Jewish comedians (Milton Berle, Sid Caesar, Groucho Marx, Red Button, Jack Benny, George Burns, along with Phil Silvers), the tail end of the decade saw a notable shift to sitcom families who were white, middle-class WASPs with picket fences and strong family values, particularly on $\mathrm{CBS}^{10}$. Yet Sgt. Bilko held out and remained popular for two more years-in spite of the fact that its star was a Jewish icon known as "The King of Chutzpah" and the fact that there was even on-screen diversity at Fort Baxter (one or two of Bilko's recruits were always African-American, for example). Bilko's ratings may have slipped, but it weathered out the western/WASPcom shift fairly well and was still popular in 1959 when CBS decided to pull the plug. CBS claimed it wanted to send the show to syndication while it was "still hot" (as it had done with I Love Lucy and The Honeymooners) and thus avoid the "fatigue factor" that it claimed had brought down so many other comedy shows ${ }^{11}$, but perhaps CBS had felt the above-mentioned shift to more conventional family comedy, and the fact that the popular shows now had a more patriotic and pro-establishment message and were shows in which authority (be it governmental or parental) was never questioned.

14 Typical of this shift, CBS replaced Bilko in primetime with a tamer and more conventional military sitcom if there ever was one, Hennesey (CBS, 1959-62, 95 ep), which was produced, directed and starred in by popular actor Jackie Cooper, who based the show on his own experiences as a WWII Navy veteran and had spent many years in the Naval Reserves. The show was more of a tribute to the honorable men and women of the armed forces, and the comedy was polite banter between the leading character, Lt. 'Chick' Hennesey, a physician at a US naval station in San Diego, California, and his patients and co-workers- 
particularly with a high-society twit of a dentist, Harvey Spencer Blair III (James Komac), and with Navy nurse Lt. Martha Hale (Abby Dalton), the perpetual love interest whom he would marry in the series finale. Though there was some mild conflict with his hardnosed commander, Cpt. Shafer (Roscoe Karns), the comedy was never slapstick or irreverent, the military itself was never lampooned as it was in Bilko, the show relied on dry humor void of a laugh track or live audience, and in the end it was more of a character study teetering between comedy and drama. However, the pro-military show only received mild ratings and would never even come close to Bilko's success, while, remarkably, Bilko's popularity carried on throughout the period, in spite of its cancellation. For three years, reruns of Sgt. Bilko remained incredibly popular. In addition, young people were given an animated remake of Sgt. Bilko through the popular primetime ABC cartoon Top Cat (1961-62, 30 ep.). The main character was a clever and scheming alley-cat (voiced by comedian Arnold Stang, who was impersonating Phil Silvers). The ragtag soldiers of Fort Brag were replaced with a gang of do-nothing alley-cats (the fattest of which, Benny the Ball, was voiced by Maurice Gosfield, reprising his role as the Costello-like Pvt. Doberman on Bilko), and the nemesis Colonel Hall was replaced with Officer Dibbie, who always failed to evict the cats from the alley ${ }^{12}$. ABC here helped keep the spirit of Bilko alive with children during primetime, just as it had done even more successfully with The Flintstones (ABC, 1960-66), a cartoon adaptation of The Honeymooners. The spirit of Ernie Bilko and his particular brand of military humor was unkillable, it seemed, and this fact would not be ignored when the second wave of military sitcoms would hit in the 1960s.

\subsection{The Spirit of Bilko Haunts the Military Sitcoms of the 1960s}

With the cancellation of Hennesey in 1962, CBS, the only network thus far to air a military sitcom, let the concept go and focused more on the above-mentioned family WASPcoms, along with the two other rather conservative comedy sub-genres that would allow CBS to stay the ratings leader throughout the 1960s: the rural sitcom [e.g., The Andy Griffith Show (1960-68) or The Beverly Hillbillies (1962-71)] along with the supernatural/rural sitcom [e.g., Mr. Ed (1961-66) or My Favorite Martian (1963-66)]. The other networks, however, seemed to have noticed how the spirit of Bilko was still going strong, through afternoon reruns and primetime cartoon lookalikes, and charged into the breach themselves. The second wave of military sitcoms, essentially from 1962-1969, would then be characterized by NBC and especially ABC's attempts to rework the Bilko model in several far less controversial variations, until CBS returned to the military sitcom in the late sixties and once again crushed the competition.

It would thus be $\mathrm{ABC}$ that would most successfully carry out its campaign to bring the military series back to primetime-and this was done on two fronts: military sitcoms and combat dramas. $\mathrm{ABC}$, possibly combining its former success with Westerns, the appeal of spy films in theaters and the appeal of patriotic tales of American heroism-had three successful military dramas during this new wave: the pensive, war-is-hell psychological drama Combat (1962-67); the popular action-packed war fantasy Rat Patrol (1966-68); as well as two less popular dramas that gloried the WWII feats of the U.S. infantry [Twelve O'Clock High (1964-67)] and of the U.S. Air Force [Gallant Men (1962-63)]. In terms of military comedies, however, $\mathrm{ABC}$ was far more successful - though their popular military sitcoms were all basically watered-down and slightly modified versions of the Bilko 
premise. After adapting the Bilko template to cartoon alley cats for Top Cat, $\mathrm{ABC}$ added live-action adaptations of the successful model to the primetime line-up. The first and most successful clone was McHale's Navy (1962-66), a somewhat shameless attempt by the network to capture the Bilko mojo that $\mathrm{CBS}$ had given up on-to such a point that $\mathrm{ABC}$ hired Bilko's former producer Edward J. Montagne along with several of the same writers and cast members, and even used the working title "Bilko Joins the Navy" behind closed doors" ("McHale's Navy", Archive...). In spite of the striking similarities [the ragtag team of stooges, the crusty commander, the Bilkoesque Lt. Commander McHale (Ernest Borgnine) who protected the former while infuriating the latter, the dim-witted Ensign Parker (Tim Conway) who played Costello to McHale's Abbott, etc.], the show focused far more on the harmless shenanigans of a silly group of crewman stationed far from any danger during wartime, and seemed stripped of Bilko's anti-establishment appeal. Riding on the success of this clone, $\mathrm{ABC}$ quickly produced two other transpositions of the Bilko model. The short-lived Broadside (1964-65) was a failed attempt to add a running women-in-a-man'sarmy gag to their McHale's Navy premise, for this time the main character is a female noncom, Lt. Anne-Morgan (Kathleen Nolan), who is stationed on a remote Navy outpost during the war and has to do battle with her misogynist commander (Edward Andrews) while protecting the WAVES she is in charge of-a group of female mechanics assigned to an all-male base as part of an experimental program. The low-brow and often demeaning humor focusing on the presence of attractive women assigned to a Navy based filled with love-starved sailors may explain the show's quick demise. The other $A B C$ sitcom, the more successful F-Troop (1965-67), once again followed the Bilko model, though this time setting the military humor at a remote army outpost at the end of the Civil War. Again, the similarities are striking: a conniving middle-ranking officer, Sgt. O'Rourke (Forrest Tucker) who outwits his inept commanding officer, Cpt. Parmenter (Ken Berry), while looking out for his band of just-as-inept soldiers, with his dim-witted sidekick Cpl. Agarn (Larry Storch) playing Costello to O'Rourke's Abbott. One slight but important modification to ABC's previous use of the model, though, was the fact that O'Rourke's foil, the camp commander, soon joins the band of lazy misfits, just as the local Indian tribe plays along with O'Rourke's schemes, so as to make the 'enemy' of all involved the American government itself and thereby restore a stronger anti-establishment message that had been sidelined since the days of Phil Silvers-though from the safe distance of a war fought one hundred years prior (See Plate 3).

Plate 3-The Bilko Model Lives on at ABC: McHale's Navy (1962-66), Broadside (1964-65) and FTroop (1965-67).

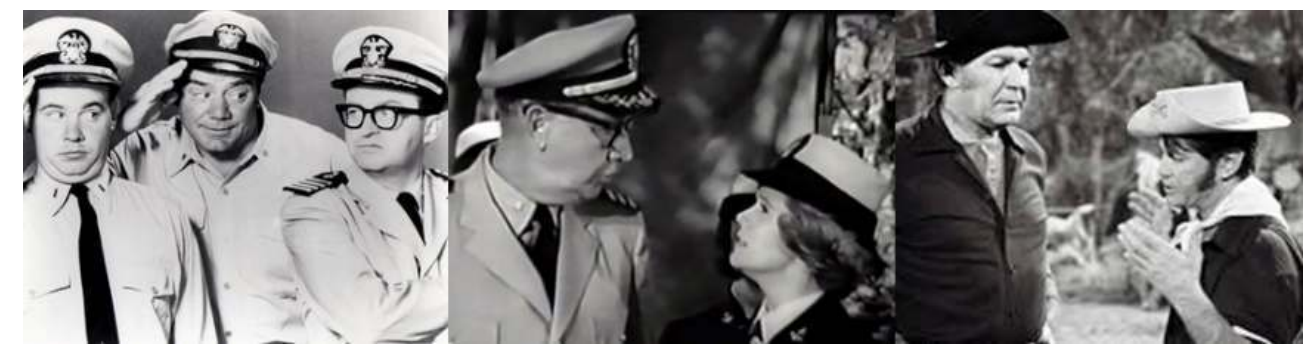

If $\mathrm{ABC}$ had some success with some of these series, notably McHale's Navy, the network did not manage to dethrone CBS from the top ratings-and rival NBC would fail even more miserably with its spate of short-lived military sitcoms during the period. To the network's merit, and unlike $\mathrm{ABC}$, their half-a-dozen military sitcoms of the period did not 
systematically copy or borrow from the Bilko model, with the exception perhaps of their first attempt, McKeever and the Colonel (1962-63), which tried to transpose Bilko into a 'students vs. instructor' dynamic by pitting smart-aleck cadet Gary McKeever against his exasperated commander at a military academy. In other series, NBC would reach back to other sources, with a slapstick adaptations of both William Lederer's 1957 novel Ensign 'Toole (1962-63) and Thomas Heggen's 1946 novel Mr. Roberts (1965-66) - though the latter was, as discussed above, one of the main sources of the Bilko model and both relied heavily on the crew-leader vs. the obstinate commander dynamic. Similarly, NBC would adapt Blake Edward's 1960 film The Wackiest Ship in the Navy into a one-hour 'dramedy' (in spite of the show's slapstick title) in 1965, borrowing the Mr. Roberts premise for a more gung-ho tribute to American bravery during World War II. In the end, these breaks from the pure Bilko model at NBC were all dead in the water, as it were, as not one of them would last more than a single season.

If CBS seemed to be sitting out this battle between its two rivals for new, popular military sitcoms, it was mainly because the network was doing extremely well with its new focus on rural sitcoms, with its Beverly Hillbillies and The Andy Griffith Show taking the highest ratings for sitcoms during the period, and in one case even managed to inadvertently undermine the other networks' attempts to have a successful military sitcom. During the period, both NBC and ABC would attempt to forego most of the Bilko template and adapt one of the most popular Broadway plays of the 1950s: No Time for Sergeants, based on the 1954 novel of the same name by Mac Hyman. The play starred Andy Griffith as Will Stockdale, a kid-hearted and seemingly moronic country bumpkin drafted into the army who in the end wins over his brothers in arms with his solid horse-sense and gentle demeanor. The play also featured Don Knotts in a memorable supporting role as quirky Corporal John C. Brown. It is understandable that both $\mathrm{ABC}$ and NBC would see this as an ideal source work for a new sitcom, for in addition to the Abbott-and-Costello-like exchanges such a series would have vast appeal to rural audiences, rival CBS's top demographic with their other sitcoms in the 1960s. However, neither network could get the iconic stage actors to do its new series, as both Griffith and Knotts were busy doing their small-town sheriff and goofy deputy shtick on CBS's number-one The Andy Griffith Show. In 1962, NBC opted to loosely adapt it with a series about a small-town country veterinarian who is shipped overseas to a sophisticated Paris military base (Don't Call Me Charlie), and in 1964, ABC would attempt to directly adapt the play but use lesser known actors, even scheduling their own No Time for Sergeants at the same time as the top CBS show that starred Griffith and Knotts. Without the iconic stars of the original play, both series failed miserably and were cancelled before the end of their first season.

To make matters worse, CBS would soon return to the military sitcom with two of the most popular series of the era, one of which was its own reworking of the No Time for Sergeants dynamic and another which was a surprising variation of their own Bilko model. For the first, CBS had immense success with its spin-off of The Andy Griffith Show, Gomer Pyle U.S.M.C. (CBS, 1964-69), which would become the number one sitcom, military or otherwise, on television by its second season and never leave the top ten during its fiveseason run. By sending the dim-witted gas station attendant Gomer Pyle (Jim Nabors) out of Mayberry and off to the Marines, CBS created a rural-military hybrid for television, thus appealing to CBS's predominantly older and more rural demographic-for Gomer Pyle, far more moronic and Costello-like than the Will Stockdale character he was loosely based on, would send his high-octane and short-tempered superior, Sgt. Carter (Frank 
Sutton) into fits of rage, but Pyle's simple country wisdom and naïve optimism would not only eventually win over his fellow Marines but also transform Sgt. Carter from nemesis to a paternal figure for the well-meaning cadet. The series was pure 'escapism', set in an alternate reality in which a young man in the sixties could spend five years in the same training camp with the same drill sergeant and never even hear mention of combat or war, a disconnection from reality that may partly explain why it was the only military sitcom on television to go up in ratings as the Vietnam conflict became more acute and problematic in the American consciousness.

Nearly as escapist and popular but far more controversial was the other military sitcom that CBS proposed throughout the late sixties: Hogan's Heroes (1965-1971), a light-hearted and slapstick adaption of Stalag 17, the 1951 play by Donald Bevan and Edwin Trzanski that was adapted in 1953 into a successful Billy Wilder film starring William Holden, Don Taylor and, remarkably, Otto Preminger as Commandant Von Scherbach. If the play and film were dark dramatic satires about a group of Allied POW's trying to get the better of their Nazi commanders in a German prisoner-of-war camp during World War II, CBS took a great risk by turning the model into slapstick burlesque ${ }^{13}$. In spite of the change in tone, it was undeniably a loose adaptation of Stalag 17, right down to the reuse of certain characters (in both works, for example, the ragtag group of POW's is guarded by an inept camp guard named Shultz), yet the series provided an alternate reality where wacky shenanigans and hilarious fun abound in a German POW camp run by goofy and inept S.S. officers. This slapstick TV version, though, owed as much to Sgt. Bilko as it did to its source film. The main conflict of the show was again based on the Bilko model-a clever middleranking conman runs a ragtag group of unorthodox misfits whose shenanigans drive their camp commander up the wall-the slight but significant switch being that this time the commander in question was of the enemy forces and the camp in question was a World War II POW camp run by the Nazis (see Plate 4). In this fantasy, Col. Robert Hogan (Bob Crane) was the ranking Allied officer held in the prisoner camp that housed several thousand allied soldiers, Stalag 13, and was the calm, dashing and intelligent leader of a ragtag group of oddball but decidedly clever Bilkoesque conmen who formed his inner circle of allied cohorts-a group that included a radio and electronics expert, a French master chef, a safe-cracker/forger and a chemist/bomb-maker. Together they effectively ran the camp, easily outwitting and manipulating both the camp commander, the incompetent and pompous Kommandant Klink (Werner Klemperer), and the sergeant-atarms who guarded their barracks, the dim-witted but loveable Hans Schultz (John Banner)-and even managed to take advantage of their proximity to German intelligence officers and of their own uncanny skills for spying and covert ops to collect intel that would help the Allies win the war. 
Plate 4-CBS Retakes the Military Sitcom Field in the Late 1960s: Gomer Pyle, USMC (1964-69) and Hogan's Heroes (1965-71)

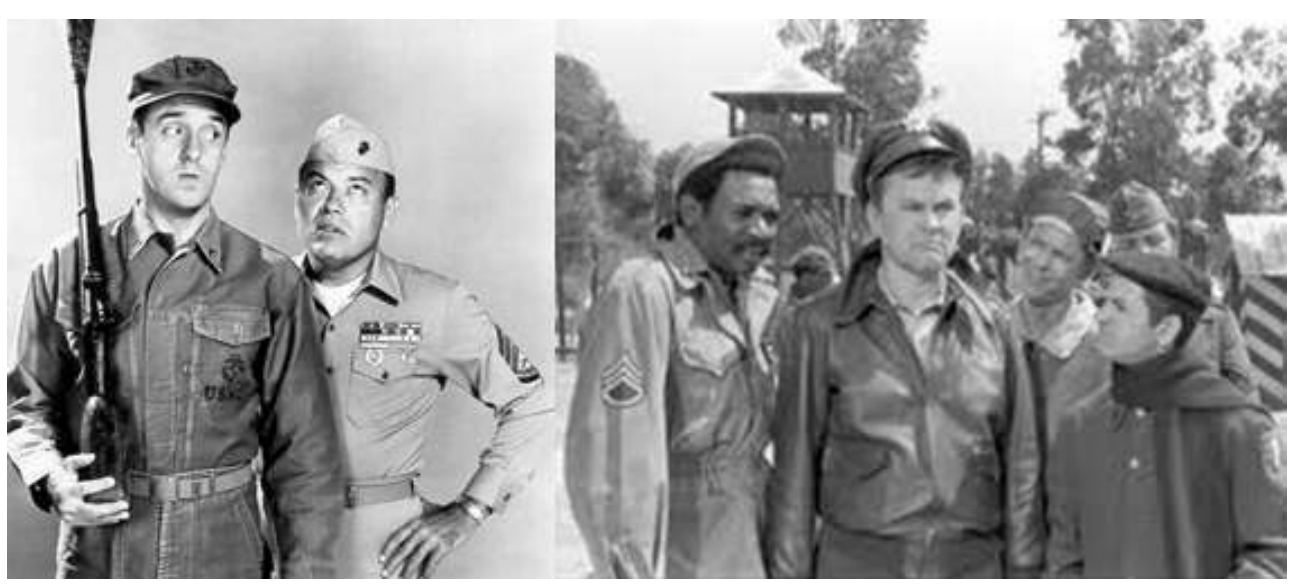

21 In spite of its burlesque premise and plot-line, Hogan's Heroes did have some groundbreaking aspects. For example, for the first time since the days of Bilko, there was an African-American among the crew. Even more importantly, the character in question, the electronics whizz James 'Kinch' Kinchlo (Ivan Dixon, later replaced by Larry Hovis as Sergeant Baker) was of such importance to the team that he seemed a second-incommand to Hogan, at a time when television had barely started to give any real visibility to African-American cast members. In addition to this new diversity, the show also provided a more realistic filming technique to the military sitcom, with establishing shots, mood lighting and suspenseful music quite at odds with its slapstick overtones. It also brought actual warfare into the military sitcom in a more obvious way than any other American program before it. Yet, the show would generate great controversy, as many were shocked that CBS, who had provided award-winning serious news coverage of World War II with its anchors Bernard Fein and Albert S. Ruddy, and whose news reports in the late 1960s were full of depressing and violent images of the growing horror of the war in Vietnam, would choose to offer "an almost obscenely comic view of the Third Reich $^{14 "}$ and the impression that war was harmless and even fun. Most of the outrage came from special interest groups and Jewish support groups, who were understandably shocked at the way the show seemed to imply that Nazis were loveable goofs and that life in a POW camp or, by extension, a concentration camp was all fun and games. CBS must have predicted this backlash, and so its secret-weapon against it would be its casting of Jewish actors for all the main German (and even French) roles ${ }^{15}$. In interviews, the many Jewish actors defended their choice to play Nazis, with Klemperer declaring that he was above all "an actor; if I can play Richard III, I can play a Nazi" ("Hogan's Heroes"), while Banner claimed his Jewishness and concentration camp experience made him the ideal choice: "Who can play a Nazi better than us Jews?" he insisted ("John Banner..."). However, these protests were somewhat countered by the show's positive representation of the US military, and this sitcom, like the others of its period, garnered no ill-will from the American government. It seemed like this vast set of "war is harmless fun" programs was just what was needed to counter the harsh "war is hell" news reports that were piped into America's living rooms just before and just after their primetime fantasy getaways.

As a whole, then, the military sitcoms of the 1960s were far greater in number than the rather monolithic first wave, yet they were far more harmless and escapist than they were controversial or anti-establishment. Nearly all used the artful dodge, invented by 
Sgt. Bilko, of making the base commander the uptight buffoon rather than the U.S. military or government itself, and nearly all were clever-or not-so-clever-reworkings of the Bilko model. Therefore, The Phil Silvers Show may have been canceled in 1959, but throughout the sixties it remained relevant through popular afternoon reruns and the huge spate of decidedly toned-down primetime lookalikes outlined above. Added to this, the programs of the sixties sidestepped any direct or even indirect connections to the military's current endeavors abroad, most notably by either setting their shows during a peacetime draft (or a wartime draft that had all the hallmarks of a peacetime draft) or setting them in past wars that either benefited, unlike the growing Vietnam conflict, from an over-powering consensus that the US had fought the good fight (i.e., World War II) or that were so remote as to make any parallel with current military operations almost impossible to make (i.e., the Civil War). Finally, even when the program was given a wartime setting, the crew was always somehow safely out of harm's way (e.g., a crew on the last ship in the fleet that never saw battle, or safely biding time in a harmless POW camp, or stationed at a supply station in the middle of nowhere, etc.). War was not hell, it seemed; it was "relatively painless fun ${ }^{16 "}$ ". Though some critics may see this as television's way of treating America's "pathology" about the growing conflict in Vietnam ${ }^{17}$, it was undeniably a form of whimsical escapism-but by the early 1970s, this TV-war-vs-realwar paradox could no longer hold, and the Bilko model would be reworked so as to become a vehicle for some of the sharpest social criticism and anti-establishment sentiment TV audiences had ever seen.

\section{2. $M^{\star} A{ }^{\star} S^{\star} H$ and the Reworking of the Bilko Model for Hard-Hitting Social Commentary} well as combat dramas, were suddenly more conspicuously absent from primetime television, and when the comic sub-genre returned in 1972, through one long-running series, $M^{*} A^{*} S^{*} H$, it would be more socially relevant and openly anti-war than any comedy program that had ever preceded it.

\subsection{From Novel to Film to TV Series}

Interestingly enough, the two main sources of the new series were two anti-war novels of the 1960s that could be seen as book-ends to the above-mentioned second television wave, though their gallows humor and harsh criticism of the U.S. military never seeped onto the small screen at the time: Joseph Heller's Catch-22 (1961) and Dr. H. Richard Hornberger's semi-autobiographical satire $M^{*} A^{*} S^{*} H$ : A Novel about Three Army Doctors (1968, under the pen name Richard Hooker). The similarities between the novels were blatantly obvious, although the former dealt with World War II and the latter with the Korean War, and these parallels concerned the fast-paced and fragmented narrative structure, the harsh tone and adult themes, the vast number of idiosyncratic if not absurd secondary characters that are quickly paraded across the pages, etc. Not surprisingly, though Hornberger's novel was less caustically anti-war, the author was nevertheless openly hailed as the new Heller, as the blurb from Ring Lardner, Jr. on the back of his novel would confirm: "Not since Catch-22 has the struggle to maintain sanity in the rampant insanity of war been told in such outrageously funny terms ${ }^{18 "}$ ". Hornberger's

TV/Series, 10 | 0000 
novel was based largely on his own experiences as a surgeon at a Mobile Army Surgical Hospital during the Korean War. The three fictional doctors mentioned in the novel's title were Benjamin 'Hawkeye' Pierce, 'Trapper John' McIntyre and Augustus Bedford 'Duke' Forrest, and the humor revolved around their reliance on golf, alcohol, skirt-chasing and practical jokes on their more gung-ho and militaristic comrades in arms.

The novel was a best-seller, as the 1968 public, as stated earlier, was as ripe for anti-war and anti-establishment sentiment as it was for new forms of narrative. The film's screenplay was written by Ring Lardner, Jr., who had been blacklisted and even imprisoned during the McCarthy witch hunts and who perhaps saw writing such an antiestablishment film as a fitting way to return to Hollywood ${ }^{19} .20^{\text {th }}$ Century Fox then struggled to find a director, as the project had been turned down by the likes of Stanley Kubrick, Sydney Lumet, Arthur Penn and Sydney Pollack before renegade TV director Robert Altman, who had written for the TV series Combat but had been fired by Fox from a previous film, Countdown (1968), took over ${ }^{20}$. If $20^{\text {th }}$ Century Fox was making a bold move with this project, top executives were still worried about bringing out an anti-war film at the height of the Vietnam War, and this seems evident through both the title card the studio insisted Altman insert in the opening scene (reading "And then there was... Korea"), and the fact that they simultaneously produced a big-budget, conservative war film - Patton (1970) - to please 'the other half', as it were, of the American audience. Both films, from opposing sides of the political spectrum, were huge successes, but the fact that Altman's film was produced at half its slated 3.5-million-dollar budget and became one of the largest-grossing films of the year seemed to confirm that public tastes in terms of war stories were changing. Altman's film also won the Palme d'Or in Cannes and was nominated for five Oscars, winning best adapted screenplay for a decidedly rehabilitated and vindicated Ring Lardner, Jr.

Fox would thus try to capitalize on this runaway success and come up with a television pilot, at a time when CBS was looking for more "relevant programming": hard-hitting and topical sitcoms, with a younger and more urban demographic, the result of their famous "rural purge" of 1971 that saw even the most popular rural and conservative sitcoms cancelled. Gene Reynolds, who had directed episodes of Hogan's Heroes and F-Troop and had recently produced ABC's Room 222, an early sitcom on diversity and tolerance, was chosen by Fox's William Self to produce and direct the show ${ }^{21}$. Reynolds knew he needed a talented writer to adapt such touchy and volatile source material, and so he contacted Larry Gelbart, who had left the U.S. for ten years following his Broadway success with $A$ Funny Thing Happened to Me on the Way to the Forum (1962) but who had felt more topical comedy writing could be done in Great Britain during the $1960 \mathrm{~s}^{22}$.

To convince Gelbart that the networks were ready for harder-hitting comedy shows, Reynolds pointed to the recent launch of All in the Family and The Mary Tyler Moore Show on $\mathrm{CBS}^{23}$. Gelbart thus joined Reynolds and the two of them brought on casting director Burt Metcalfe as associate producer, and the now famous 'trio' of $M^{*} A^{*} S^{*} H$ creators was complete $^{24}$. They in turn convinced Alan Alda to take on the leading role of Hawkeye Pierce. Alda was a critically acclaimed screen and stage actor whose first TV appearance had fittingly been as a starving artist on a Sgt. Bilko episode and who had made a name for himself in the 1960s through noted appearances on TV shows such as That Was the Week that Was (NBC, 1964-65) and a starring role in George Plimpton's 1968 feature film The Paper Lion, an adaptation of Truman Capote's novel on the plight of un-masculine or effeminate men in prison ${ }^{25}$. Alda's combination of quick wit, sharp delivery, versatility 
and clear dedication to more liberal causes made him the perfect choice for the role of Hawkeye, a character that had to be able, within a single episode, to go from doing a Groucho Marx impersonation, to delivering a zinger on military incompetence, to singing a show-tune, to being dead serious in the OR, to using a great pick-up line on a nurse ${ }^{26}$. The pilot aired on Sept 17, 1972, and CBS seemed to warily schedule the show in an unpopular Sunday night slot, as if testing the waters before assuring it broad viewership. It was indeed a slow start, with $M^{*} A^{*} S^{*} H$ ranking only $47^{\text {th }}$ in overall ratings, but initial reviews seemed positive and there were no angry calls from the White House as CBS had experienced with certain episodes of The Smothers Brothers or of All in the Family. CBS then moved $M^{*} A^{*} S^{*} H$ to its popular and topical Friday-night line-up, sandwiching it between All in the Family and The Mary Tyler Moore Show, thereby juxtaposing the three longest running and most influential sitcoms of the decade and forming what David Marc has rightfully called "the triptych of seventies America ${ }^{27 "}$ ". Unlike the other two 'relevance' programs, however, $M^{*} A^{*} S^{*} H$ would not branch out into a vast number of spin-offs and clones throughout the decade, although the ground-breaking military sitcom would have two failed attempts at sequels in the mid-1980s.

$M^{*} A^{*} S^{*} H$ seemed to be in class by itself and quickly grew in popularity and critical acclaim, winning a total of 14 Emmy Awards between 1974 and 1982, and culminating in a two-and-a-half-hour series finale that was the highest-rated single television program to date, garnering a whopping $77 \%$ of the television audience ${ }^{28}$. In addition, the series has been translated into 15 different languages, has aired in 25 countries, and has been the subject of over two dozen book-length studies ${ }^{29}$.

\subsection{Making Key Changes for Television and Bringing in the Bilko Model}

There were of course many factors that contributed to such a phenomenal and lasting success, most of which came from knowing what to keep, what to change and what to add to the source material. Much like the novel and film, the series sought to be a perfect hybrid of comedy and tragedy, of irreverent banter and the horrors of war, of juvenile pranks and decidedly adult themes. The producers knew, however, that many of the more shocking elements of the film had to be toned down for network television, which could never reproduce the film's post-Hay's Code liberties in terms of nudity, profanity and vivid operating-room gore. Thus 'sex' was reduced to flirting, kissing and doubleentendre, profanity was limited to generic but heart-felt indignation or occasional racial slurs (e.g., "spear-chucker", "gook") in the mouths of unsavory characters, while bloodcovered surgeon's smocks replaced disturbing shots of open wounds. Yet, if the pendulum did not swing as far into the realm of luridness as the film, the adult themes it pointed to were still there, and that same pendulum also swung even further in the other direction in the series-that is, into the realm of slapstick comedy and irreverent repartee.

This was not easy to pull off on television, as past attempts and blending the two genres had leaned too far in the direction of drama to be funny (e.g., The Wackiest Ship in the Army ) or too far in the direction of slapstick humor to have a serious message (nearly every other military sitcom of the 1960s). Yet $M^{*} A^{*} S^{*} H$ managed to perfectly combine both the "War Is Funny" approach of prior sitcoms like Hogan's Heroes with the "War Is Hell" approach of prior combat dramas like Combat. Though the series began with no pre-credit warning on the show's use of humor to underline serious themes, as All in the Family did, 
there is an episode in the first season in which Hawkeye, in voice-over, writes a letter home to his father that explains how humor should be seen as their coping mechanism. It almost reads as if it were sent to the show's viewers: "If jokes seem sacrilegious in the operating room, I promise you they are a necessary defense against what we get down here at this end of the draft board" (1.12).

Like the film and novel, the series also used a past war, the Korean War (1950-53), to surreptitiously criticize the current and more controversial conflict in South-East Asia, the Vietnam War, a ruse mildly attempted earlier on television with ABC's F-Troop. This could be called an "anachronistic shell-game" - as $M^{*} A^{*} S^{*} H$ would indirectly criticize a current war while taking great pains to maintain historical accuracy for an older war. Reynolds, Gelbart and Metcalfe went far beyond the source material in their attempts to ensure historical accuracy, taking several research trips themselves to South Korea, documenting real war experiences from doctors and nurses in such MASH units, using details from William L. White's book Back Down Ridge, which carefully explained what an American soldier wounded in battle went through step by step, hiring military and medical advisors such as Dr. Walter Dishell to make sure that the jargon was appropriate for the time and setting, and even using a 1950s Sears \& Roebuck catalogue to make sure clothing and decor were spot on $^{30}$. There were some necessary inaccuracies, of course, such as the fact that real-life $\mathrm{M}^{*} \mathrm{~A}^{*} \mathrm{~S}^{*} \mathrm{H}$ units were far more "mobile", as the first word of the acronym suggests, than the $4077^{\text {th }}$ was in the long-running series ${ }^{31}$. However, one of the most common jabs at the show is that the three-year war lasted over eleven years on television, but this is simply an attempt to turn the show's success against itself, and one is tempted to remind such detractors that the series lasted exactly as long as the Vietnam War it covertly lampooned.

Added to this attempt at wartime realism were the filming techniques used on the program, some of which were similar to those used in Altman's film, others that were its own devices, and none of which had been mobilized in a TV series before, let alone on a sitcom. It had a quick-paced, movie-like rhythm, successive short scenes and cross-cuts between multiple plot-lines, varied narrative formats from one episode to another, occasional ironic contradiction between voice-over narration and related images, blurred and subjective vision devices, and grainy film quality at times that reminded viewers of war documentaries or even newsreels. These realistic and experimental devices were countered by zany studio antics and a careful use of the laugh track. One should note that the producers decided never to use the laugh track in any OR scenes on the show or at any other time when the tone was dark or solemn, regardless of the number of clever jokes that might pepper the scene to alleviate the tension ${ }^{32}$. A result of this was the occasional episode that had nearly no laugh track at all, such as the experimental episode "O.R.", in which entire episode chronicles one incredibly long shift in the Operating Room as the wounded keep streaming in, to such a point that Hawkeye and Captain Blake have to let a badly wounded soldier die so as to have enough time and plasma to save several others (3.05).

In terms of the series' narrative structure as compared to its sources, the most obvious changes concern characterization and again prove to be a reworking of the basic military sitcom conventions established by Sgt. Bilko in the 1950s, though this time with a more caustic result. If the novel and film focused on a trio of surgeons, the series dropped the "Duke the Southerner" character completely, leaving Hawkeye Pierce (Alan Alda) and Trapper John McIntyre (Wayne Rogers) as the leading duo for the first seasons. Yet, 
although Rogers had been signed first and was promised that the two leads would be on equal footing and nearly as interchangeable as they were in the film, Alda's popularity with the public would lead writers to make Trapper more a congenial side-kick to Hawkeye, the unofficial leader of the camp, thus making the latter the undisputed main character of the show and the Bilkoesque leader of the misfits at the $4077^{\text {th }}$. He became the main point of view character almost immediately, narrating the first episode and countless episodes to follow; he was at once the scheming instigator, the main source of the show's wit, the program's moral consciousness and the mouthpiece for the show's anti-establishment and anti-military discourse. As Gerard Jones puts it, he was "the Bilkolike conniver and joker but with a dark side" that provided the bulk of the show's depth ${ }^{33}$. Thus, through a reshuffling of the film and novel's main characters, the producers provided a new and far more socially aware version of the Bilko model.

Another change from the novel and film was the relationship between the ragtag crew and its commander. In previous military sitcoms, as we have seen, the main nemesis for the unconventional Bilko character and his crew was their unbending or inept commander, so as to focus the anti-militaristic ire on a single individual rather than the US military or its ideology as a whole. However, as the series sought to do just the opposite and openly lampoon or criticize war in general and the U.S. army in particular, this antagonism was superfluous. Instead, the commander was now another odd but loveable member of the group of misfits. Colonel Blake (McLean Stevenson), a sorrowfully inept administrator but a top-notch surgeon, could not keep Hawkeye's antics in check, nor did he really want to, quickly adopting the "if you can't beat 'em join 'em" complicity that had been first toyed with in the ABC series F-Troop. When Blake was replaced by Colonel Potter (Harry Morgan), an older, seemingly hard-nosed old-school military type, one might have thought that the 'maverick vs commander' dynamic had returned, yet Potter was instead a facilitator for Hawkeye and his crew, using his mastery of army bureaucracy to get things done, and became the beloved father-figure of the $4077^{\text {th }}$ family unit for its last eight seasons. Thus, another traditional convention of military sitcoms was clearly reworked to serve the show's main focus.

As for the secondary characters that made up the ragtag crew of the $4077^{\text {th }}$, there was again a vast reworking of those presented in the novel and film. Some were simply dropped for the television adaptation (e.g., Captains "Painless Pole" Waldowski, Murrhardt, Bandini, Scorch and McCarthy), but there was one quite noticeable addition: Corporal Klinger (Jamie Farr), who provided both Milton-Berlesque comic relief as a hairy G.I. in drag as well as a constant anti-war message, as his cross-dressing was an open ruse to try get a Section 8 discharge and get sent home. The secondary characters who remained were slightly reworked: shy but efficient Corporal Radar O'Reilly (Gary Burghoff, the only actor to play his role in both the film and the series) was given more focus as the mild-mannered non-com who managed to cut through red tape and practically run the unit in the stead of his inept superiors; Major Frank Burns (Larry Linville) was made more of a ridiculous dimwit than the film role as played by Robert Duvall; his love interest Major Margaret "Hot Lips" Houlihan (Loretta Swift) was given more competence and depth of character (in spite of her unbending need for propriety and protocol) than in the source works, and Father Mulcahy (William Christopher) was changed from a meddling zealot to the kindest soul at the camp. However, given the format, these secondary characters were given a far less cursory treatment than in the two-hour film or the novel's quick succession of quirky secondary characters. The years- 
long series format of course allowed for much more intense character development over time, and these so-called secondary characters became both more complex and more endearing to the public, thereby quickly rising to the ranks of main characters and equally well-loved members of the $M^{*} A^{*} S^{*} H$ family long before their departure or the show's end (see Plate 5).

\subsection{A Vehicle for Anti-Establishment Sentiment and 1970s Social Causes}

37 Where the series was most similar to the novel and film was of course in its anti-war and anti-establishment message, a liberal and pacifist leaning that was, as stated above, already greatly outweighing pro-Vietnam War sentiment in the U.S. by the time the series began. However, one could argue that while the film and novel's anti-war message was delivered in a fast-paced and visceral manner, the series could take the time to include a more gradual and didactic approach, most often using Hawkeye's dialogue, come-backs or voice-over narration as its main vehicle. As stated above, the series was designed so as to praise the brave men and women serving in the military while openly mocking the ludicrousness of the war itself and the downright stupidity of the U.S. military. For example, in "The Interview" (4.25), viewers follow a black-and-white documentary on the $4077^{\text {th }}$ filmed, as it were, by a group of American journalists, a documentary stressing the paradox of the interviewees' feelings about their mission-i.e., pride in their work but hatred of the war itself. Thus the army itself and particularly its gung-ho higher-ups who callously or carelessly put Americans in harm's way were openly ridiculed or scorned. A good example of this can be found in the episode entitled "Some $38^{\text {th }}$ Parallels" (4.20), in which Hawkeye arranges to have a helicopter dump a load of garbage on an unfeeling Colonel Croner, who had unnecessarily sent troops into a losing battle-a visual metaphor for the way the brass was treated on a regular basis on the series. The show also went to great lengths to regularly mock the anti-Communist rhetoric that was the driving force of the Korean (and Vietnam) War, and this ranged from regular jabs at conservative icons such as MacArthur, McCarthy and Eisenhower, to using the loudest laugh tracks to undermine the blindly patriotic and anti-Communist rhetoric of Frank Burns or that paragon of blind militarism, Colonel Flagg, to providing memorable speeches by Hawkeye, such as the oft-quoted lines he delivers regarding America's supposedly 'noble' mission in Korea:

I don't know why they're shooting at us. All we want to do is bring them democracy and white bread, to transplant the American dream: freedom, achievement, hyperactivity, affluence, flatulence, technology, tension, the inalienable right to a coronary at your desk while plotting to stab your boss in the back $(3.05$, quoted in Jones, p. 240).

Similarly, Hawkeye and his crew often took swipes at the American news media and its biased presentation of the war effort for audiences back home. One regular technique for this was the use of the camp's PA system, which, as it did in the film, touts politically correct and positive pro-war announcements that ring hollow both by the piped America pop songs in Chinese or Korean that accompany them and by the blatant contrast between the actual announcement and what we know to be the truth. At other times, entire episodes were dedicated to stressing the subjectivity of war news media coverage, as in the early episode "Yankee Doodle Doctor" (1.06). In it, Frank gives patriotic testimony for a photo journalist's report, but Hawkeye and Trapper secretly re-edit the 
news report to provide images that coldly or ridiculously contrast Frank's proud voiceover, even adding two extra segments: a burlesque rendition of a Marx Brothers' sketch and a final direct message from Hawkeye, standing behind a severely wounded soldier, to viewers (imaginary or real) at home:

Three hours ago, this man was in a battle. Two hours ago, we operated on him. He's got a 50-50 chance. We win some, we lose some. That's what it's all about. No promises. No guaranteed survival. No saints in surgical garb. Our willingness, our experience, our technique are not enough. Guns, and bombs, and anti-personnel mines have more power to take life than we have to preserve it. Not a very happy ending for a movie. But then, no war is a movie (1.06).

If the show's anti-war message was present throughout the entire run of the series, it seems undeniable that it was strongest from 1973-75-that is, from just prior to just after the end of America's involvement in Vietnam. This peak seemed to be bookended by two particularly hard-hitting anti-war episodes. In "Sometimes You Hear the Bullet" (1.17), a young soldier named Wendell Peterson (quite symbolically played by young Ron Howard, then known to American audiences as Andy Taylor's son Opie on The Andy Griffith Show, the epitome of conservative sitcoms of the 1960s) is treated for a battle wound by Hawkeye and confides in him that is too young to serve and had lied about his age because he believes whole-heartedly in America's mission to bring democracy to the "gooks". Hawkeye promises to keep his secret and tries to deflate his naïve and gung-ho battle-ego, but when a friend of Hawkeye's, a war journalist, is killed, Hawkeye breaks his promise and has the MPs arrest Wendell and send him home, out of harm's way. The final exchange is memorable, as an unforgiving Wendell swears "I will never forgive you for this-not for the rest of my life!"-to which Hawkeye replies "Let's hope it's a long and healthy hate." Turning America's beloved and kind-hearted Opie Taylor into a dangerously gung-ho war hawk was a stroke of genius and gave the anti-war message even more impact. The peak of this anti-war rhetoric seemed to come at the end of the third season, just six weeks before the real-life Saigon fell to the North Vietnamese, and when the show's loveable Colonel Blake is finally sent home after years of loyal service, only to be killed when his helicopter is shot down on its way out of Korea in one of the show's most gut-wrenching episodes.

If the anti-war message was by the show's very nature and origins the main antiestablishment and countercultural theme, it was far from the only one. And if the novel and film's other main theme was an attack on religious orthodoxy and hypocrisy, it is clear that this was greatly toned down in the TV series. Unlike the annoying religious zealot of the novel, CBS's Father Mulcahy is the most kind-hearted and open-minded soul at the camp. The series opted instead for more subtle jabs at religious hypocrisy, particularly through religious-right characters like Frank Burns and Margaret Houlihan. For example, in the opening sequence of the pilot, the two majors are seen piously reading their bibles at a table (while other cast members play golf or football until the next shipment of wounded), but the camera pans down under the table to reveal them provocatively playing footsie with their bare feet, immediately revealing their secret love affair and their hypocrisy to audiences.

41 If the series can thus be said to have played up one main theme of the novel and film while playing down another, many of the other countercultural and liberal themes had nothing to do with the show's sources and much more to do with controversial social issues of the 1970s. It is in these additional and didactic anti-establishment messages of tolerance that $M^{*} A^{*} S^{*} H$ truly joins the ranks of CBS's two other icons of "relevance 
programming", The Mary Tyler Moore Show and especially All in the Family. It is also this broadening of the targets of the show's ire that could explain why the source novel's author, Richard Hornberger, actually a staunch conservative, felt that the series was too disrespectful of the establishment, whereas he glowingly approved the film adaptation ${ }^{34}$. Perhaps by broadening the scope from the original anti-war and anti-religious messages of its sources, the series had, in Hornberger's mind, been hijacked by a broader and more liberal 1970s agenda.

One of Altman's only negative remarks concerning the novel had been what he saw as its "racist" overtones, perhaps because the only black character was named "Spearchucker" and was the butt of racist jokes on the part of the main character Duke the Southerner. The TV series would instead strive to teach tolerance in terms of racial differences and even interracial marriages, capitalizing on the fact that Korea was the first war to see blacks and whites more fully integrated in battle and military ranks. In the series, Dr. "Spearchucker" Jones, the camp's leading brain surgeon, began the series bunking with Hawkeye and Trapper and was thus initially seen as part of the main 'trio' of jokesters (see Plate 5), a replacement for his racist antagonist from the novel, Duke. However, the Jones character was only kept for four episodes, possibly as part of the efforts to focus the show on a more Bilko-like Hawkeye and his side-kick Trapper. The series would thus instead dedicate certain episodes to the theme of black-white racism. These include the early episode entitled "Dear Dad...Three" (2.09), in which a racist white patient named Sgt. Condon, who had insisted on being given the "right type" of blood (i.e., Caucasian blood), is tricked into believing he was given African-American blood and that he was turning black (Hawkeye and Trapper dye his skin gradually darker throughout the episode); similarly, in a later episode, "The Tooth Shall Set You Free" (10.14), Hawkeye and BJ discover that a racist commander, Major Weems, is intentionally sending AfricanAmerican soldiers to the front lines to die in disproportionate numbers, and they trick him into resigning from the military.

Plate 5-The Initial Cast of $M^{\star} A^{\star} S^{\star} H$ and the early presence of Dr. "Spearchucker" Jones.

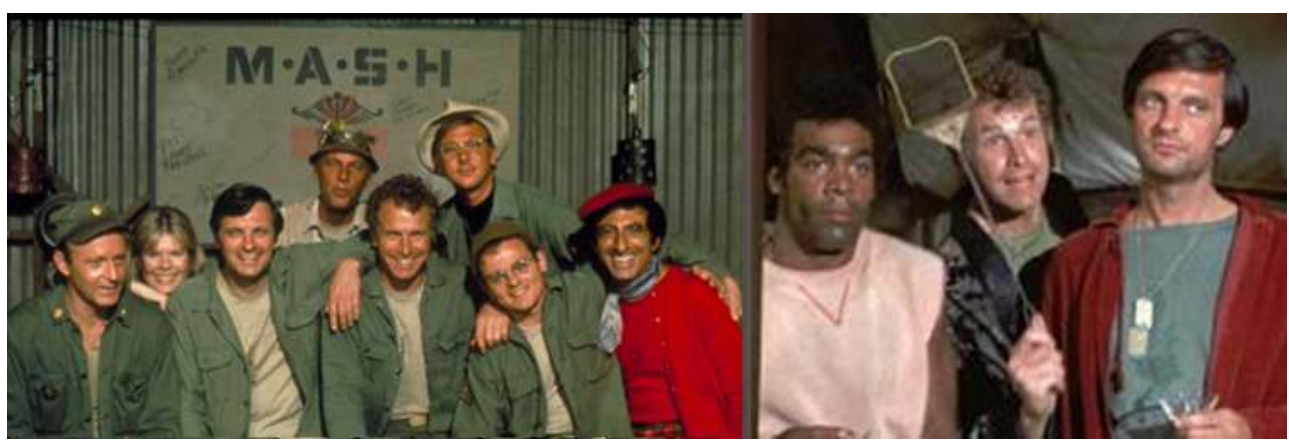

In addition, the theme of racism was also frequently broached in terms of the treatment of Asians. This was often delivered by a quick quip from Hawkeye, either to outspokenly racist Frank Burns when he referred to the North Koreans as "Yellow Reds", or through one-episode characters such as the above-mentioned Pvt. Wendell (Ron Howard), who proclaims that he cannot wait to get out of the hospital and "kill me some more gooks", to which Hawkeye replies, "Another word for gooks is people" $(3.05,1.17)$. Other episodes would be fully dedicated to theme of racism against Asians, and particularly to interracial marriage between Caucasian G.I.'s and South Koreans. This is the focus of the episode "Local Indigenous Personnel" (2.07), in which Corporal Phil Walker has a baby with and 
plans to marry a Korean girl. Hawkeye's girlfriend, attractive nurse Lt. Ginger Bayliss, makes ugly, bigoted remarks concerning a wedding she finds unnatural, and Hawkeye instantly puts her in her place and severs the relationship. The theme would of course return in the series finale when Klinger trades in his dress for a tuxedo and marries his Korean fiancée, Soon-Lee ${ }^{35}$.

The scourge of discrimination against homosexuals was another semi-recurrent theme that could nevertheless have been given more direct and regular treatment on the series. Corporal Klinger, a cross-dresser in flowery sundresses and high-heels, could have been used as a vector for this, and the character was indeed initially sketched by writers as an effeminate gay man struggling in a misogynist and homophobic American military environment ${ }^{36}$ (Wittebol 29). In the end, however, Klinger was reduced to a means of comic relief and was instead explicitly presented as a straight man willing to go to ridiculous lengths to get out of the army. Still, in spite of this back-pedaling on Klinger's sexuality, the show seemed far more gay-friendly than the novel ${ }^{37}$. However, there was one episode that specifically dealt with discrimination of gays in the military. In "George" (2.22), Hawkeye and Trapper treat two American soldiers-one an African-American, the other a gay Caucasian-who were not wounded by the enemy but violently beaten by their racist and homophobic comrades-in-arms. The doctors manage to save them both from their attackers and, in the case of the gay soldier, Pvt. George Weston, from the dishonorable discharge Frank Burns tries to initiate to help keep gays out of the army. As mild as this call for tolerance may sound today, we must remember that Pvt. Weston was one of the first openly gay characters to appear on American television, appearing three years to the day after the first such character, Roger 'the Fairy', appeared on the fifth episode of All in the Family, in a similarly anti-discriminatory episode (1.05) that sent shock waves through the American public, right up to Nixon's Oval Office ${ }^{38}$.

Finally, perhaps the call for tolerance that received the least frequent treatment on the program was that of women's rights. The basic premise of the show - philandering doctors in a 1950s war that saw very few women in a position of power - was bound to regularly treat women as sexual objects and disappoint feminist viewers. Perhaps the one saving grace on this note is the rewriting of the character of Major Margaret Houlihan. Though she initially appears, as in the film, as a hypocritically prim and proper, protocolsavvy officer who, together with her dimwitted and equally hypocritical fiancé, Major Frank Burns, are the regular victims of Hawkeye and Trapper's practical jokes and goading, she quickly evolves past Frank's two-dimensionality and is seen as a woman of strength and power, an excellent head-nurse, and a woman who is far more tolerant and has more moral depth than initially imagined. Over the course of the show, she even manages to shake her derogatory nickname "Hot Lips" (garnered by a prank in which Hawkeye and Trapper had Radar hide the camp microphone under her bed and broadcast her and Frank's pillow talk to the entire camp). This occurs in an episode called "The Grim Reaper" (6.12), in which Hawkeye and Houlihan find themselves trapped alone in a farmhouse that is being bombarded, and both characters let their guard down and discover common ground and common needs. After that, she will forever be called "Margaret" on the show. In the end, the rehabilitation of Margaret Houlihan into a pseudo-feminist icon would allow her to join the ranks of more obvious landmark feminist characters on CBS's "relevance" programs, such as Gloria Bunker, Maude Findlay or Mary Richards. 

making Klinger an outright homosexual struggling in the army and made Houlihan a strong and sympathetic feminist character from day one, the series would have made a much stronger countercultural statement in terms of racism, gay rights and feminism, issues that, unlike sister shows from Norman Lear or Mary Tyler Moore and their numerous spin-offs of the period, were not the main focus of the show's overall antiestablishment impact and liberal leaning. One should also remember that even light treatment of such subjects was something new and ground-breaking in the early to mid-1970s, and that the main anti-war and anti-military message certainly pulled no punches. $M^{*} A^{*} S^{*} H$ did indeed represent the zeitgeist of the early seventies in America, when counterculture and anti-war sentiment were finally overtaking the traditional, conservative face of television. Some cultural historians try to use this fact to declare the show a mainstream program and even conservative program with a countercultural gloss -as it began at a time when an ever-growing majority was indeed already against the war and militaristic ideology and was thus just 'going with the flow' of a national trend ${ }^{39}$. Yet this seems to ignore that fact that a good part of the public still had (and still have) opposing, decidedly conservative views, and that this was still something more radical and controversial than anything that had been shown on American television prior to 1971 and the launch of All in the Family. Others correctly notice that the sitcom became less edgy and radical by the late seventies, and by the early eighties had nearly dropped controversy altogether to instead focus on interrelations between the beloved characters the public had grown so attached too-an assessment, by the way, that could be applied verbatim to its long-running Friday-night sister-show, All in the Family. Though true, this should not be seen as either of the shows "selling out". The zeitgeist of the late Vietnam and Nixon era, when the two shows began, was quite different from that of the Reagan years of the early to mid-1980s, when the shows were winding down. Perpetuating, into the 1980s, the shows' initially hard-hitting, in-your-face calls of the early seventies to fight the established order and conservative values of the 1950s and 1960s would have been both out of sync with the shows' audience and simply beating a dead horse. $M^{*} A^{*} S^{*} H$ had indeed successfully carried out its mission, as it had above all exorcized America's demons with the Vietnam War, through the Trojan Horse of television comedy, and paved the way for the large number of feature films of the late 1970s and 1980s to finally more openly deal with the Vietnam War.

$M^{*} A^{*} S^{*} H$ thus so completely fulfilled its mission as a break-through military sitcom for the 1970s that it left little or no room for any competition, and it alone constituted the third and final wave of military sitcoms on American television, just as Sgt. Bilko had stood alone in the $1950 \mathrm{~s}^{40}$. In the end, $M^{*} A^{*} S^{*} H$ certainly deserved all the accolades it received when it was finally retired from television with great pomp and circumstance in February of 1983, in what is still the highest-rated series finale in the history of American television -what's more, it deserved a Medal of Honor.

\section{Conclusion}

The military sitcom, though constantly shifting, was thus a mainstay of US primetime programming over three decades, though it developed in three distinct stages, each of which had its own dominant tone and its own level of social relevancy and impact. Among the most common threads, however, was clearly the importance of the initial Bilko model

TV/Series, 10 | 0000 
in terms of comedic devices and situational conflict, much of which was a combination of numerous features from two earlier comedic film franchises: the Abbott and Costello franchise in the early 1940s and the Mister Roberts franchise of the late 1940s and early 1950s.

As demonstrated throughout this study, the Bilko model not only outlived the other forms of anti-establishment, anti-authority humor of the 1950s, but it continued after the program's cancellation, through afternoon syndication, primetime cartoons and especially a score of water-down avatars throughout the 1960s. For this second stage, the Bilko model was tweaked so as to strip it of its anti-establishment veneer and often reduced to slapstick escapism, creating quite the paradox-that of having no real treatment of the U.S. military at a time when U.S. forces were involved in a controversial war in Vietnam. The programs of this second stage had much in common - their lack of relevancy, the disappearance of an anti-establishment message, their appeal to rural audiences, an anti-elitist and anti-intellectual message, the promotion of the unsinkable American spirit and good old-fashioned horse sense, etc. Though many might consider such escapism a much-needed palliative for a country at war, it seems safe to say that it was far too sugar-coated a pill to have any real effect on the patient's symptoms. Indeed, it would only be with the arrival of $M^{*} A^{*} S^{*} H$ in the 1970s for the third and final stage that the Bilko model would again be reworked into a far more topical variation and that the right dosage of hard-hitting realism and slapstick comedy would be discovered to help cure the nation's ills. Thus the comedic conventions that started with Bilko, along with the source novel and film's story-lines and characters, were all reshuffled so as to better deal not only with the anti-war and anti-establishment sentiment that started in the late 1960s but also with a broad spectrum of liberal causes of the 1970s-from fighting religious piety and especially racism, against both blacks and Asians, to defending feminism and gay rights. The palliative did come then, though not in the placebo form that was being offered during the 1960s. $M^{*} A^{*} S^{*} H$ would thus prove that a true hybrid of wartime realism and irreverent slapstick comedy was not only possible, it was just what the doctor ordered.

The Bilko model, in a variety of guises, had thus served very well for three decades, and in the end it had kept CBS at the top of the ratings throughout. The network was quite savvy in ability to adapt the model to its changing audience over time, knowing when to use it and when to abandon it for more conservative rural fare, when to resurrect it in more fantasy escapist formats and when to reinvent it as a vehicle for a full frontal attack on the very conservative values it had previously touted.

In the end, the military sitcom seems to have decidedly been a product of the post-war generation, for the end of $M^{*} A^{*} S^{*} H$ was basically the end of the sub-genre on American television. For the next twenty years, the only thing close to a military sitcom would be CBS's mildly successful Major Dad (1989-93), which focused more on a hard-nosed Marine's family life and struggles raising three daughters than on a military setting. Very recently, there was Fox's disastrous attempt to resurrect the genre with Enlisted (2014)-the contemporary story of three brothers who find themselves stationed in the same army camp in Florida. Though it too could be seen as a modern reworking of the Bilko model, the program was canceled after only nine of its first thirteen episodes had aired.

However, one should note that the death of the military sitcom was by no means the death of the Bilko model, as the successful narrative set-up was quickly and successfully 
expanded to civilian settings. Towards the end of $M^{*} A^{*} S^{*} H^{\prime}$ s run, for example, $\mathrm{ABC}$ had already come up with two popular sitcoms that successfully transposed the Bilko model to other settings-that of a high school and that of a police station. Welcome Back, Kotter (1975-79) gave viewers a group of unruly high school losers under the wing of a witty and manipulative educator, Gabe Kotter, who defends them from the uptight and unbending vice-principal, Mr. Woodman. Similarly, in Barney Miller (1975-82), police Cpt. Miller found himself in charge of a squad room full of oddball characters, fighting local crime, inflated egos and incomprehensible bureaucracy in the NYPD. Even on today's television, the 'demilitarized' Bilko model is still a mainstay. Brooklyn Nine-Nine (Fox, 2013-present) reestablishes the Barney Miller squad room sitcom, but focuses even more on a zany conman, Sgt. Jake Peralta (Adam Samberg), as the central Bilko-character and unofficial leader of the gang of misfits. Similarly, the irreverent sitcom Community (NBC and Yahoo! Screen, 2009-2015), quite strictly adheres to the Bilko model, with Jeff Winger (Joel McHale) as the clever conman and leader of a ragtag group of students at Greendale Community College, in constant conflict with the pretentious and flamboyant Dean Pelton (Jim Rash).

One can only wonder, then, why the military sitcom seemed to die with the final episodes of $M^{*} A^{*} S^{*} H$, while the Bilkoesque narrative set-up would live on in so many other forms. Had $M^{*} A^{*} S^{*} H$ successfully exorcised the American consciousness of its demons of war (that is, of WWII, Korea and Vietnam)? When America returned to controversial overseas military engagements in the 1990s and 2000s (The Gulf War, The Iraq War, The War in Afghanistan), why did the military sitcom not return to American television? Had the subgenre run its course? Were producers too wary of inevitable comparisons to the landmark success of $M^{*} A^{*} S^{*} H$ ? Were the reruns of the many series discussed in this paper enough to satiate any possible desire for the format on the part of the viewing public, or perhaps was the television landscape simply too politically correct to again attempt that oxymoronic hybrid of blending war and comedy? Whatever the explanation, the military sitcom has long since retired from the ranks of American television, though in its glory days it had indeed dominated primetime television and helped America come to terms with its own identity as a nation of war.

\section{BIBLIOGRAPHY}

ALTMAN Robert, Altman on Altman, ed. David Thompson, London, Faber \& Faber, 2006.

APEL Otto F., MASH: An Army Surgeon in Korea, Lexington, University Press of Kentucky, 1998.

ARLEN Michael J., Living-Room War, New York, Viking Press, 1969.

BASINGER Jeanine, The World War II Combat Film: Anatomy of a Genre, New York, Columbia UP, 1986.

"Bilko on Parade", Televised Interview with Phil Silvers, Interviewer: Kenneth Baxter, Producer: BBC1, Nick Freand Jones, BFI Archives, 1984.

BUDD Mike and STEINMAN Clay, "M*A*S*H Mystified: Capitalization, Dematerialization, Idealization," Cultural Critique, Fall 1988, p. 59-74. 
DIFFRIENT David Scott, $M^{*} A^{*} S^{*} H$, Detroit, Wayne State University Press, 2008.

EDGERTON Gary R, The Columbia History of American Television, New York, Columbia University Press, 2007.

FURMANEK Bob and Ron Palumbo, Abbott \& Costello in Hollywood, New York, Perigree Books, 1991.

GITLIN Todd, Inside Prime Time, New York, Pantheon Books, 1983.

HALBERSTAm David, The Power that Be, New York, Alfred A. Knopf, 1974.

HALL Ken, "Celebrity Artist: Robert Clary", Go-Star.Com, 14 Feb. 2004. Discontinued and archived at http://archive.today/mqCoi

НАмАмото Darrell Y, Nervous Laughter: Television Situation Comedy and Liberal Democratic Ideology, New York, Praeger Press, 1989.

“Hogan's Heroes”, World Public Library / World Heritage Encyclopedia, http://netlibrary.net/article/ WHEBN0000146550/Hogan consulted April 4, 2014.

“Interview: John Banner, aka ‘Sergeant Schultz” Query”, Art History Forum, 20 Dec. 2007.

JONES Gerard, “Honey, I'm Home": Sitcoms: Selling the American Dream, New York, St. Martin's Press, 1992.

KALTER Suzy, The Complete Book of $M^{*} A^{*} S^{*} H$, New York, Abradale, 1988.

LEVINE Ken, “The Truth about $M^{*} A^{*} S^{*} H^{\prime}$, By Ken Levine: The World as Seen by a TV Comedy Writer, Sept. 17, 2009, http://kenlevine.blogspot.fr/2009/09/truth-about-mash.html consulted May 4, 2014.

LEWISOHN Mark, "The Phil Silvers Show”, The BBC.co.uk Guide to Comedy http://archive.today/ oV7cs

"McHale's Navy", Archives of American Television, http://www.emmytvlegends.org/interviews/ shows/mchales-navy consulted May 15, 2014.

MCNEIL Alex, Total Television: A Comprehensive Guide to programming from 1948 to the Present, $2^{\text {nd }}$ ed., New York, Penguin Books, 1984.

MARC David, Comic Visions: Television Comedy and American Culture, Malden (MA), Blackwell Publishers, 1989, 1997.

NATIONAL ARCHIVES, “Military Records: Statistical Information about Fatal Casualties during the Vietnam War", U.S. National Archives website, http://www.archives.gov/research/military/ vietnam-war/casualty-statistics.html ROYCE Brenda Scott, Hogan's Heroes: Behind the Scenes at Stalag 13, New York, Renaissance Books, 1998.

TREDY Dennis, “Those Were the Days...': All in the Family and the 'Primetiming' of U.S. Diversity and Counterculture." Expressions artistiques et politiques de la contre-culture : La Contestation en images, 1955-1975. Revue E.O.L.L.E. Vol. II, n4 (Dec. 2012), https://gric.univ-lehavre.fr/IMG/pdf/ tredy.pdf

WATERS Harry F, “Farewell to the 'MASH' Gang” Newsweek, 28 Feb. 1983, p. 44-50.

WIETRAuB Bernard, “Werner Klemperer, Klink in Hogan's Heroes, Dies at 80", The New York Times, 8 Dec. 2000. 
wittebol James W., Watching $M^{*} A^{*} S^{*} H$, Watching America: A Social History of the 1972-1983 Television Series, Jefferson (NC), McFarland, 2003.

WORLAND Rick, “The Other Living-Room War: Prime Time Combat Series 1962-1975," Journal of Film and Video 50.3, Fall, 1998, p. 3-23.

\section{APPENDIXES}

\section{Films and TV series quoted}

Pride and Prejudice (Robert Z. Leonard, 1940)

Buck Privates (Arthur Lubin, 1941)

In the Navy (Arthur Lubin, 1941)

Keep 'Em Flying (Arthur Lubin, 1941)

You're in the Army Now! (Lewis Seiler, 1941)

The George Burns \& Gracie Allen Show (CBS, 1950-58)

I Love Lucy (CBS, 1951-1957)

The Jackie Gleason Show (Dumont 1950-52, CBS 1952-57)

The Adventures of Ozzie and Harriet (ABC, 1952-66)

The Honeymooners (CBS, 1955-56)

Father Knows Best (CBS, 1954-60)

Mr. Roberts (John Ford, 1955)

You'll Never Get Rich / The Phil Silvers Show (CBS, 1955-59)

Sgt. Bilko (CBS, 1955-59)

Leave It to Beaver (CBS, NBC, 1957-63)

Operation Petticoat (Blake Edwards, 1959)

Jackpot Bowling (NBC, 1959-1961)

Hennesey (CBS, 1959-62)

Dennis the Menace (CBS, 1959-63)

The Wackiest Ship in the Navy (Blake Edwards, 1960)

The Flintstones (ABC, 1960-66)

The Andy Griffith Show (CBS, 1960-68)

The Wackiest Ship in the Army (Richard Murphy, 1961)

You're in the Picture (CBS, 1961)

Top Cat (ABC, 1961-62)

Mr. Ed (CBS, 1961-66) 
Don't Call Me Charlie (NBC, 1962)

Gallant Men (ABC, 1962-63)

McKeever and the Colonel (NBC, 1962-63)

Ensign 'Toole (NBC, 1962-63)

McHale's Navy (ABC, 1962-66)

Combat (ABC, 1962-67)

The Beverly Hillbillies (CBS, 1962-71)

My Favorite Martian (CBS, 1963-66)

No Time for Sergeants (ABC, 1964)

Broadside (ABC, 1964-65)

That Was the Week that Was (NBC, 1964-65)

Twelve O'Clock High (ABC, 1964-67)

Gomer Pyle U.S.M.C. (CBS, 1964-69)

F-Troop (ABC, 1965-67)

The Wackiest Ship in the Army (NBC, 1965-1966)

Mr. Roberts (NBC, 1965-66)

Hogan's Heroes (CBS, 1965-1971)

Rat Patrol (ABC, 1966-68)

Countdown (Robert Altman, 1968)

The Paper Lion (George Plimpton, 1968)

The Smothers Brothers Comedy Hour (CBS, 1967-1969)

Room 222 (ABC, 1969-1974)

Patton (Franklin J. Schaffner, 1970)

The Mary Tyler Moore Show (CBS, 1970-77)

All in the Family (CBS, 1971-79)

$M^{*} A^{*} S^{*} H(\mathrm{CBS}, 1972-1983)$

Welcome Back, Kotter (ABC, 1975-79)

Barney Miller (ABC, 1975-82)

CPO Sharkey (NBC, 1976-1978)

Seinfeld (NBC, 1989-1998)

Community (NBC and Yahoo! Screen, 2009-2015)

Brooklyn Nine-Nine (Fox, 2013-present) 


\section{NOTES}

1. Janine Basinger, The World War II Combat Film: Anatomy of a Genre, New York, Columbia University Press, 1986.

2. Bob Furmanek and Ron Palumbo, Abbott \& Costello in Hollywood, New York, Perigree Books, 1991, p. 42-48.

3. To truly understand the importance of Bilko as a pioneer in the military sitcom, it is necessary to understand what the TV comedy landscape was like at the time. Primetime line-ups were dominated by comedy hours and variety shows that were hosted by extremely popular comic emcees and that combined stand-up, musical numbers and occasional short 'blackout' sketches with popular characters the host had created [e.g., a sketch about a loudmouth bus-driver named Ralph Kramden was a popular blackout sketch on The Jackie Gleason Show (Dumont 1950-52, CBS 1952-57) and became the landmark sitcom The Honeymooners (CBS, 1955-56, 39 episodes) in 1955, premiering at the same time as You'll Never Get Rich]. A vast majority of sitcoms at the time were either TV adaptations of radio shows, such as The Adventures of Ozzie and Harriet (ABC, 1952-66), outgrowths of sketches from televised comedy hours like The Honeymooners, or only slightly fictionalized retellings of the star's real life, often starring the spouse and even the children of the star [e.g., I Love Lucy (CBS, 1951-1957), The George Burns \& Gracie Allen Show (CBS, 1950-58), etc.]. Sgt. Bilko, in addition to being the first military sitcom, was also one of the first sitcoms not to be adapted from a popular radio or variety show.

4. Gerard Jones, “Honey, I'm Home”: Sitcoms: Selling the American Dream, New York, St. Martin's Press, 1992, p. 113.

5. Ibid., p. 114.

6. 'Non-com' is military slang for a 'non-commissioned officer', often abbreviated NCO. It refers to a low-ranking officer who has not yet earned a commission, what many countries refer to as a 'sub-officer'.

7. Another hallmark of the cleverness of the show's writing can be seen in its recurrent metafictional touches, perhaps in part the result of the tendency in 1950s sitcoms to have the stars play fictionalized versions of themselves. Thus, the above-mentioned trip to the psychiatrist is a parody of Silver's own experience with therapy in the early fifties. In another episode, Sgt. Bilko is asked to consult on a film and is mistreated by the studio boss, a jab at L.B. Mayer and his MGM studios (1.16), with whom Silvers had had a harrowing experience when he was originally miscast to play Reverend Collins in Pride and Prejudice in 1940, and in another episode he is asked to help create a TV show based on life at Fort Baxter, the dialogue with the studio executives being a parody of how Silvers's own show was created (2.21). (See Kenneth Williams's 1984 interview with Fred Silvers, "Bilko on Parade" for more details on these metafictional dimensions). Note that the most popular sitcom of the 1990s, Seinfeld, used many of these same devices, particularly a recreation of the negotiations with NBC to launch a "show about nothing"-not to mention that Seinfeld's banter was also openly and admittedly inspired by Abbott and Costello exchanges, and that Seinfeld, like Sgt. Bilko, ends with its main characters, much to the joy of their usual victims, being sent to prison.

8. Jones, p. 116.

9. This was the case, for example, for Milton Berle, whose comedy hour first dropped in ratings because it was scheduled at the same time as Sgt. Bilko and was dealt a fatal blow by the new appeal of westerns, relegating the once-stellar Milton Berle to hosting NBC's 1960 Jackpot Bowling; similarly Jackie Gleason would be recycled by 1961 to host CBS's gameshow You're in the Picture.

10. These included Father Knows Best (CBS, 1954-60), Leave It to Beaver (CBS, NBC, 1957-63) and the most popular sitcom of 1959, Dennis the Menace (CBS, 1959-63). Thus, by the end of the decade, 
black and white sitcoms had become particularly white, as well as Protestant, middle-class, conventional and values-oriented.

11. Jones, p. 118.

12. Ibid., p. 169.

13. a drastic change in tone that would in fact save it from a heavy lawsuit filed by Stalag 17 authors Beven and Trzanski in 1965, when they sued the network for copyright infringement, particularly as their own script for a TV adaptation of their play had been rejected by CBS, see Brenda Scott Royce, Hogan's Heroes: Behind the Scenes at Stalag 13, New York, Renaissance Books, 1998 , p. 22.

14. David Halberstam, The Power that Be, New York, Alfred A. Knopf, 1974, p. 417.

15. For example, Werner Klemperer (Commandant Klink) was a German Jew who had fled Germany in 1933 (Weintraub); both John Banner (Sgt. Schultz) and Leon Askin (General Burkhalter) had been prisoners in pre-war Nazi concentration camps, and both had lost family members at Treblinka and other camps during World War II ("John Banner..."). In addition, many other actors playing Germans were American Jews, such as Howard Caine (as Major Hochstetter). Most surprisingly, the actor who played the main character "Frenchie" Lebeau, Robert Clary, a French Jew, not only spent three years (1942-1945) as a prisoner at the Nazi concentration camp of Ottmuth, but he lost twelve immediate family members at Auschwitz, and in Hogan's Heroes he is indeed always seen in long sleeves so as to hide his tell-tale tattooed serial number,"A-5714" (Ken Hall, "Celebrity Artist: Robert Clary", Go-Star.Com, 14 Feb. 2004). The implied argument seemed to be that if actual victims of Nazi concentration camps had no qualms about parodying the Nazis and in fact took an ounce of vindication from the chance to ridicule them as brainless buffoons, then why should anyone else.

16. Rick Worland, “The Other Living-Room War: Prime Time Combat Series 1962-1975," Journal of Film and Video, 50.3, Fall 1998, p. 15.

17. See, for example, Darrell Hamamoto, Nervous Laughter: Television Situation Comedy and Liberal Democratic Ideology, New York, Praeger Press, 1989, p. 59 : “The denial of the war in Vietnam in combination with intense domestic discord became part of the psychopathology of everyday life in the U.S. It was as if the fictional worlds played out in military situation comedies internalized the turmoil of the times and relieved anxiety through the use of humor".

18. David Scott Diffrient, $M^{*} A^{*} S^{*} H$, Detroit, Wayne State University Press, 2008, p. 21

19. Ibid.

20. Ibid., p. 21-22.

21. Jones, p. 238.

22. Ibid.

23. Jones, p. 239.

24. Diffrient, p. 27-31; David Marc, Comic Visions: Television Comedy and American Culture, Malden (MA), Blackwell Publishers, 1989, 1997, p. 155-57.

25. Diffrient, p. 29-30.

26. Ibid., p. 32.

27. Marc, p. 133.

28. Alex McNeil, Total Television: A Comprehensive Guide to programming from 1948 to the Present, $2^{\text {nd }}$ ed., New York, Penguin Books, 1984, p. 391.

29. Among these numerous studies of the series, many lean more toward the fan-friendly episode guide than toward more scholarly analysis. Among the most thorough and serious studies are James W. Wittebol's Watching $M^{*} A^{*} S^{*} H$, Watching America: A Social History of the 1972-1983 Television Series (Jefferson, NC: McFarland, 2003) and David Scott Diffrient's $M^{*} A^{*} S^{*} H$ (Detroit: Wayne State UP, 2008), which benefits from access to UCLA's Arts Library Special Collection of actual notes, scripts, memos and correspondences of producers and writers of show, includes a deeper focus 
on contradictions and racial stereotyping on the program, and was a key source for much of the information in this section of our study.

30. Otto F. Appel, MASH: An Army Surgeon in Korea, Lexington (KY), University Press of Kentucky, 1998, p. 118-19; Diffrient, p. 12-13.

31. For example, the actual $4055^{\text {th }}$ Korean MASH unit relocated 27 times in the first sixteen months of the war, and interviews with veterans from such units all told of the need to pack up and ship out on an all too regular basis, whereas in the 11 years of the series a need to possibly lift camp is only mentioned on three occasions (Diffrient, p. 13). As Diffrient suggests, this was certainly due to the logistical need to shoot the series in the same location (Fox Ranch in Calabassa, California), but it could also be that the audience needed to remain in the one camp, and in the company of its endearing characters, which it had come to know so well (Ibid.).

32. Worland, p. 16.

33. Jones, p. 240.

34. Harry F. Waters, "Farewell to the 'MASH' Gang”, Newsweek, 28 Feb 1983, p. 50.

35. For an in-depth discussion of the contradiction between such calls against racism towards Asians and the perpetuating of Asian stereotypes on the series, see Chapter 8 of David Scott Diffrient's study, $M^{*} A^{*} S^{*} H(103-122)$.

36. James W. Wittebol, Watching $M^{*} A^{*} S^{*} H$, Watching America: A Social History of the 1972-1983 Television Series, Jefferson (NC), McFarland, 2003, p. 29.

37. For a more detailed analysis of the treatment of LGBT issues in general and of the character of Klinger in particular, see my article "Kind of a Drag... ": Gender-Bending in Early 1970s American Sitcoms and Comedy Programs (with special focus on NBC's The Flip Wilson Show, ABC's The Odd Couple and CBS's $\left.M^{*} A^{*} S^{*} H\right)$ " in the upcoming edition of Représentations: Revue éléctronique du CEMRA (Université Stendhal-Grenoble III): http://representations.u-grenoble3.fr/spip.php? rubrique 9

38. In the episode, entitled "Judging Books by Covers", it is later revealed that 'Roger the Fairy' is not gay, but that Archie Bunker's manly drinking buddy Steve is. For more on this key episode of All in the Family and on President's Nixon violent reaction to it, see my article "'Those Were the Days...': All in the Family and the 'Primetiming' of U.S. Diversity and Counterculture." Expressions artistiques et politiques de la contre-culture : La Contestation en images, 1955-1975. Revue E.O.L.L.E. Vol. II, ${ }^{\circ} 4$ (Dec. 2012). https://gric.univ-lehavre.fr/IMG/pdf/tredy.pdf

39. Mike Budd and Clay Steinman, " $\mathrm{M}^{*} \mathrm{~A}^{*} \mathrm{~S}^{*} \mathrm{H}$ Mystified: Capitalization, Dematerialization, Idealization," Cultural Critique, Fall 1988, p. 59-74, Diffrient, p. 12.

40. In the 1970s, NBC and ABC would indeed each make one brief attempt to rework older models of the sub-genre from the 1950s and 1960s. NBC's short-lived CPO Sharkey with Don Rickles (1976-78) was basically a combination of Sgt. Bilko and All in the Family, with loud-mouthed insult comic Don Rickles playing a drill sergeant who tries to overcome his conservative prejudices and deal with the new face of the Navy, one that includes blacks, Hispanics and women. ABC would try to resurrect a 1959 feature film by Blake Edwards, Operation Petticoat, with its slightly more modern television adaptation in 1977, adding a bevy of female sailors to the original premise involving a conniving and resourceful sailor (Lt. Grant) and his frustrated but complicit commander (Lt. Commander Holden) and their antics on board a pink submarine. But these hackneyed formats understandably never found an audience and died a quick death from low ratings. They also were so overshadowed by the $M^{*} A^{*} S^{*} H$ phenomenon that they are completely forgotten today. 


\section{ABSTRACTS}

This article provides a detailed study of the origins and the development of the American military sitcom, a subgenre that began in the 1950s with The Phil Silvers Show, better known as Sgt. Bilko, peaked in the 1970s with $M^{*} A^{*} S^{*} H$, and has been retired from the small screen ever since. The heyday of the 'war comedy', an oxymoron if there ever was one and a TV staple for the postWorld War II generation, was made up of three distinct waves, each with a different tone or message in spite of their slapstick parallels and often similar narrative set-ups. The late 1950s set the standard with CBS's ground-breaking Sgt. Bilko, which combined features of key wartime comedy films of the 1940s and 1950s with star Phil Silvers quick-witted, trickster persona to provide a sharp if hilarious anti-establishment message. Then came the 1960s and a slew of watered down Bilko lookalikes on other networks and some new models on CBS, all of which were surprisingly light-hearted and escapist, especially when one remembers that they were sandwiched between harrowing news reports on the horrors of the ongoing war in Vietnam. In the early 1970s, CBS would again rework the Bilko model when adapting $M^{*} A^{*} S^{*} H$, already a popular novel and film, for television and thereby create the most powerful vehicle for anti-war sentiment and for dozens of other liberal causes ever to be aired on television. This article will thus pay particular attention to the first and the last series in this long parade of military sitcoms, focusing on their origins and their lasting influence, their tone and style, their use as a key weapon in the networks' war for ratings, and their ability to deliver a strong antiestablishment message through the Trojan Horse of laughter.

Cet article examine les origines et l'évolution de la « sitcom militaire » à la télévision américaine, un sous-genre qui commence dans les années 1950 avec la série The Phil Silvers Show, mieux connue sous le nom de Sgt. Bilko, atteint son point culminant dans les années 1970 avec $M^{*} A^{*} S^{*} H$, puis disparait mystérieusement des écrans de télévision. Cet âge d'or de la " comédie de guerre ", drôle d'oxymore et type d'émission alors très apprécié par la génération après-guerre, arrive par trois vagues bien distinctes, chacune avec un style et un message bien différents malgré leurs similitudes en termes de prémisse et d'humour déjanté. La chaîne CBS établit les normes à partir de 1955 avec Sgt. Bilko, émission phare fortement influencée par certains films comiques de la décennie précédente mais qui donne carte blanche au personnage filou et vif d'esprit créé par le comique Phil Silvers, donnant une dimension clairement «anti-establishment " à la série. La deuxième vague, pendant les années 1960, consiste en une multitude de copies bien moins acerbes du modèle Bilko sur les autres chaînes et quelques nouveaux modèles sur CBS, tous des échappatoires légers et farfelus à la dure réalité de la guerre au Vietnam présentée dans les journaux télévisés de ces mêmes chaînes. Enfin, CBS fait à nouveau cavalier seul dans les années 1970 en réutilisant son modèle Bilko pour encadrer son adaptation télévisée de $M^{*} A^{*} S^{*} H$, déjà un roman et un film à succès, donnant naissance à une série qui véhiculera non seulement un très fort message anti-guerre et anti-gouvernemental mais défendra aussi de nombreuses causes progressistes de l'époque. Une attention toute particulière sera donc accordée à la première et à la dernière série de ce long défilé de "sitcoms militaires", afin de souligner leurs origines et leurs influences, leur ton et leur style inédits, leur instrumentalisation dans la guerre d'audimat entre les trois grandes chaînes américaines, et leur capacité à livrer un très fort message contestataire à travers le Cheval de Troie culturel et politique qu'est la comédie télévisuelle. 


\section{INDEX}

Mots-clés: sitcoms militaires, guerre, comédie, années 1950, années 1960, années 1970, Bilko, Silvers Phil, $\mathrm{M}^{*} \mathrm{~A}^{*} \mathrm{~S}^{*} \mathrm{H}$, networks, anti-establishment, Papa Schultz, Abbott et Costello, guerre du Vietnam, guerre froide, guerre de Corée, messages politiques

Keywords: military sitcoms, war, comedy, 1950s, 1960s, 1970s, Hogan's Heroes, Abbott and Costello, Vietnam War, Cold war, Korean War, political messages

\section{AUTHOR}

\section{DENNIS TREDY}

Dennis Tredy est maitre de conférences en Littérature américaine à l'université de Paris IIISorbonne nouvelle. Il est co-fondateur de l'ESJS (European Society of Jamesian Studies) et a publié récemment deux ouvrages sur Henry James: Henry James and the Poetics of Duplicity (2013) et Henry James's Europe: Heritage and Transfer (2011). En plus de ses publications sur James et d'autres romanciers américains, il a écrit sur les adaptations filmiques et televises des oeuvres d'Henry James, Edgar Allan Poe et Vladimir Nabokov. Son travail récent sur les séries televisées s'est concentré sur les premières sitcoms, les adaptations de la littérature gothique et de programmes radio, ainsi que sur les représentations de la culture américaine, de la diversité et de la contreculture dans les années 1950, 1960 et 1970.

Dennis Tredy is an associate professor of American Literature at the Université de Paris III Sorbonne Nouvelle. He is co-founder of the ESJS (European Society of Jamesian Studies) and has published two recent volumes on Henry James: Henry James and the Poetics of Duplicity (2013) and Henry James's Europe: Heritage and Transfer (2011). In addition to his publications on James and on other American novelists, Dennis has published studies of film and television adaptations of the works of Henry James, Edgar Allan Poe and Vladimir Nabokov. His recent work on TV series has centered on early sitcoms, on the adaptation of gothic literature and of radio programs for television, as well as on the representation of American culture, diversity and counter-culture on television in the 1950s, 1960s and 1970's. 